\title{
Comparison of selected physical fitness components among male football players of different playing positions
}

\author{
Vishaw GAURAV1, Amandeep SINGH², Sukhdev SINGH² \\ ${ }^{1}$ Department of Education, Government of Punjab, India. \\ 2 Department of Physical Education (T), Guru Nanak Dev University, Amritsar, India. \\ Address Correspondence to Amandeep Singh, prof_aman@yahoo.com
}

\begin{abstract}
The purpose of this study was to examine the level of physical fitness among male football players in relation to their different playing positions i.e. goalkeepers, defenders, midfielders and attackers. A sample of forty $(\mathrm{N}=40)$ male football players (mean \pm SD: age $20.45 \pm 1.70$ years, height $1.84 \pm 4.07 \mathrm{~m}$, weight $81.62 \pm 5.45 \mathrm{~kg}$, BMI $23.99 \pm 1.66 \mathrm{~m}$ ), which includes ten each goalkeepers, defenders, midfielders and attackers, who participated in inter-college competitions of Guru Nanak Dev University, Amritsar, India, was selected. All the participants were informed about aim and methodology of the study and they volunteered to participate in this study. The study was conducted on selected physical fitness variables i.e. power, speed and agility. One way Analysis of Variance (ANOVA) was applied to find out the significance of differences with regard to selected physical fitness variables among football players of different playing positions. Scheffe's post-hoc test was applied to see the direction and significance of differences where ' $F$ ' value found statistically significant. The level of significance was set at 0.05 . While comparing the means, it is revealed that midfielders and attackers had almost the same power, speed and agility. However, midfielders and attackers had shown better power and agility than their counterparts; goalkeepers and defenders. Further, significant differences were found between football players of different playing positions with regard to the variables power $(p<0.05)$ and agility $(p<0.05)$, but insignificant differences were found on the variable speed respectively $(\mathrm{p}>0.05)$.
\end{abstract}

Keywords: Agility, attackers, defenders, goalkeepers, midfielders, power, speed.

\section{INTRODUCTION}

Football is the most popular sport in the world $(24,25)$. Physical and Physiological characteristics that have been reported as essential for football players are aerobic fitness, muscle strength, high level of speed, explosive jumping power and agility $(2,4,16)$. Generally football players are divided into four categories regarding playing position. There are goalkeepers, defenders, midfielders and attackers, and each has its own characteristics. Attackers appear to be the fastest players in the team. The greatest overall distances appear to be covered by midfield players who act as links between defense and attack (18.19). In a football game defenders perform more backward movement than attackers (19). Furthermore, different football related activities (i.e.tackling, heading and passing) provide an extra physiological stress to the player (4) with different playing positions having to perform specific activities. Positional differences have been the subject of interest of sport scientists for years $(1,4,10,17)$. The physical fitness of a player however can be a decisive determinant of success during competition (22). Previous studies have reported that each specific playing position may have unique physical and physiological requirements $(6,8,9)$. Thus, the purpose of this study was to compare the physical fitness characteristics of football players among different playing positions.

\section{MATERIALS \& METHODS}

\section{Subjects}

A sample of forty $(\mathrm{N}=40)$ football players (mean $\pm \mathrm{SD}$ : age $20.45 \pm 1.70$ years, height $1.84 \pm 4.07 \mathrm{~m}$, weight $81.62 \pm 5.45 \mathrm{~kg}$, BMI $23.99 \pm 1.66 \mathrm{~m}$ ), which includes ten each goalkeepers, defenders, midfielders 
and attackers, who participated in inter-college competitions of Guru Nanak Dev University, Amritsar, India, was selected. All the participants were informed about aim and methodology of the study and they volunteered to participate in this study.

\section{Methodology}

Height measurements were taken by using the standard anthropometric rod to the nearest $0.5 \mathrm{~cm}$. Taken values were recorded in ' $\mathrm{cm}$ '. The subject's weight was measured with portable weighing machine to the nearest $0.5 \mathrm{~kg}$. Measurements were recorded in ' $\mathrm{kg}^{\prime}$. BMI was calculated by the formula of; Body Mass Index $=$ Weight $/$ Height $^{2}$.The vertical jump test (12) was used to measure explosive power of the legs whereas 50 meters dash test was used to determine speed (13). Illinois agility test was used to measure agility (15).

\section{Statistical Analyses}

The Statistical Package for the Social Sciences (SPSS) version 16.0 was used for all the analyses. One way Analysis of Variance (ANOVA) was applied to find out the significance of differences with regard to physical fitness variables among goalkeepers, defenders, midfielders and attackers in football. Scheffe's post-hoc test (SPHT) was applied to see the direction and significance of differences where ' $\mathrm{F}$ ' value found statistically significant. The level of significance was set at 0.05 .

\section{RESULTS}

Table 1 shows the mean values and standard deviations of male football players of different playing positions i.e. goalkeepers, defenders, midfielders and attackers with regard to the selected physical fitness variables i.e. power, speed and agility. While comparing the means, it is revealed that midfielders and attackers had almost the same power, speed and agility. Moreover, both had shown better power and agility than their counterparts; goalkeepers and defenders. It is also observed that goalkeepers had little bit lesser speed than their counterparts; defenders, midfielders and attackers.

Further it is evident from table -2 that significant differences were found between football players of different playing positions with regard to the variables power $(p<0.05)$ and agility $(p<0.05)$, but insignificant differences were found on the variable speed $(\mathrm{p}>0.05)$ respectively.

Table 1. Mean and standard deviation of selected physical fitness components of male football players of different playing positions.

\begin{tabular}{|c|c|c|c|c|c|c|c|c|}
\hline \multirow{3}{*}{ Variables } & \multicolumn{8}{|c|}{ Playing Positions } \\
\hline & \multicolumn{2}{|c|}{ Goalkeepers $(\mathrm{N}=10)$} & \multicolumn{2}{|c|}{ Defenders $(\mathrm{N}=10)$} & \multicolumn{2}{|c|}{ Midfielders $(\mathrm{N}=10)$} & \multicolumn{2}{|c|}{ Attackers $(\mathrm{N}=10)$} \\
\hline & Mean & $\mathrm{SD}$ & Mean & $\mathrm{SD}$ & Mean & SD & Mean & SD \\
\hline Power $(\mathrm{cm})$ & 46.40 & 4.50 & 55.60 & 7.88 & 59.60 & 10.35 & 59.60 & 10.35 \\
\hline Speed (sec) & 6.84 & 0.34 & 6.53 & 0.48 & 6.55 & 0.20 & 6.55 & 0.20 \\
\hline Agility (sec) & 18.64 & 1.34 & 16.74 & 0.32 & 16.70 & 0.77 & 16.70 & 0.77 \\
\hline
\end{tabular}

Table 2. Analysis of variance (ANOVA) of selected physical fitness components of male football players of different playing positions.

\begin{tabular}{|c|c|c|c|c|c|c|}
\hline Variables & Source of variance & Sum of Squares & $\mathrm{df}$ & Mean Square & F-value & Sig. \\
\hline \multirow[t]{3}{*}{ Power } & Between Groups & 1162.800 & 3 & 387.600 & $5.227^{*}$ & 0.004 \\
\hline & Within Groups & 2669.600 & 36 & 74.156 & & \\
\hline & Total & 3832.400 & 39 & & & \\
\hline \multirow{3}{*}{ Speed } & Between Groups & 0.663 & 3 & 0.221 & 2.069 & 0.122 \\
\hline & Within Groups & 3.844 & 36 & 0.107 & & \\
\hline & Total & 4.507 & 39 & & & \\
\hline \multirow[t]{3}{*}{ Agility } & Between Groups & 27.792 & 3 & 9.264 & $12.097^{*}$ & 0.000 \\
\hline & Within Groups & 27.569 & 36 & 0.766 & & \\
\hline & Total & 55.361 & 39 & & & \\
\hline
\end{tabular}

*Significant at .05 level of Confidence; $\quad$ F.05 $(2,39)=3.24$ 
Table 3. Comparison of mean values of Post-hoc Test (Scheffe's) of male football players of different playing positions with regard to selected physical fitness variables.

\begin{tabular}{|c|c|c|c|c|c|c|}
\hline \multirow{2}{*}{ Variable } & \multicolumn{4}{|c|}{ Playing Positions } & \multirow{2}{*}{ Mean Difference } & \multirow{2}{*}{$\mathrm{p}$} \\
\hline & Goalkeepers & Defenders & Midfielders & Attackers & & \\
\hline \multirow[t]{6}{*}{ Power } & 46.40 & 55.60 & & & 9.20 & 0.15 \\
\hline & 46.40 & & 59.60 & & $13.20^{*}$ & 0.01 \\
\hline & 46.40 & & & 59.60 & $13.20^{*}$ & 0.01 \\
\hline & & 55.60 & 59.60 & & 4.00 & 0.78 \\
\hline & & 55.60 & & 59.60 & 4.00 & 0.78 \\
\hline & & & 59.60 & 59.60 & 0.00 & 1.00 \\
\hline \multirow[t]{6}{*}{ Agility } & 18.64 & 16.74 & & & $1.90^{*}$ & 0.00 \\
\hline & 18.64 & & 16.70 & & $1.94^{*}$ & 0.00 \\
\hline & 18.64 & & & 16.70 & $1.94^{*}$ & 0.00 \\
\hline & & 16.74 & 16.70 & & 0.04 & 1.00 \\
\hline & & 16.74 & & 16.70 & 0.04 & 1.00 \\
\hline & & & 16.70 & 16.70 & 0.00 & 1.00 \\
\hline
\end{tabular}

*Significant at .05 level of Confidence

Table 3 showed paired means of different playing positions in football; it revealed statistically significant differences $(p<0.05)$ of goalkeepers with midfielders \& attackers, however, insignificant differences $(p>0.05)$ of defenders with goalkeepers, midfielders \& attackers and also of midfielders with attackers, with regards to the variable power. Further, it revealed statistically significant differences $(p<0.05)$ of goalkeepers with defenders, midfielders \& attackers but insignificant differences $(p>0.05)$ of defenders with midfielders \& attackers and also of midfielders with attackers, with regard to the variable agility.

\section{DISCUSSION}

Physical fitness is defined as the individual's capacity for optional work and motor and sport performance (3). The findings of present study revealed that midfielders and attackers had almost the same power, speed and agility. Moreover, both had shown better power and agility than their counterparts; goalkeepers and defenders. The results of present study are dis-agree with Gil et al. (14) who showed that attackers were faster than defenders and midfielders at the $30 \mathrm{~m}$ sprint test. It is also observed that goalkeepers had little bit lesser speed than their counterparts; defenders, midfielders \& attackers. Sporis et al.(23) evaluate the physical and physiological characteristics of elite players in various positions and concluded that the goalkeeper in tests of 10 and 20 meters are slower than other players. Boone et al. (7) in the study on the Belgian elite players showed that attackers had more speed than other players. Significant differences have been found among football players of different playing positions with regard to the variables power and agility, but insignificant differences were found on the variable speed respectively. While comparing paired means of different playing positions in football; goalkeepers have shown statistically significant differences with midfielders \& attackers, however, defenders have shown insignificant differences with goalkeepers, midfielders \& attackers and also of midfielders with attackers, with regards to the variable power. However, the higher power was found among midfielders \& attackers as compared to their counterparts; differences and goalkeepers. A football player who is agile is able to change direction abruptly without losing balance. Agility helps a player's ability to get and hold onto the ball (21). In our study, we found that there is a significant difference between the various positions of the football players. Indeed, midfielders \& attackers present the best performance in agility test, on the other hand the defenders are faster than the goalkeepers. These results confirm the fact that midfielders \& attackers are technically more developed than the defenders and the goalkeepers in football. It was found that there were differences in the physical fitness level associated with playing positions. This was supported by Reeves et al. (20) who found that there were differences in the 
anthropometric characteristics and body composition associated with playing position.

\section{CONCLUSION}

It is concluded that midfielders and attackers had almost the same power, speed and agility. Moreover, midfielders and attackers had also shown better power and agility than their counterparts; goalkeepers and defenders.

\section{REFERENCES}

1. Al-Hazzaa HM, Alumuzaini KS, Al-Rafaee A, Sulaiman MA, Dafterdar MY. Al-Ghamedi A, Khuraiji KN. Aerobic and anaerobic power characteristics of Saudi elite soccer players. J Sports Med Phys Fitness, 2001; 41: 54-61.

2. Arnason A, Sigurdsson SB, Gudmundsson A. Holme I. Engebretsen L. Bahr R. Physical fitness, Injuries, and Team performance in soccer. Med.Sci. Sport Exerc, 2004; 36 (2): 278285.

3. Astrand PO, Rodahl K. Textbook of work physiology: Physiological basis of exercise $(3$ ed.). New York: Macmillian.1986.

4. Bangsbo J. The physiology of soccer with special reference to intense intermittent exercise. Acta Physiologica Scandinavia.1994; 151 (619), 1-156.

5. Bangsbo J, Norregaard L, Thorsoe F. Activity profile of competition soccer. Canadian Journal of applied sports science.1991; 16: 110-116.

6. Bloomfield J, Polman R, O'Donoghue P. Physical demands of different positions in FA Premier League soccer. Journal of Sports Science and Medicine, 2007. 6(1): p. 63-70.

7. Boone J, Vaeyens R, Steyaert A, Bossche LV, Bourgois J. Physical fitness of elite Belgian soccer players by player position. J Strength Cond Res.2912; 26(8):2051-7.

8. Bunc V, Psotta R. Physiological profile of very young soccer players. Journal of Sports Medicine and Physical Fitness, 2001; 41(3): 337-341.

9. Burgess DJ, Naughton G, Norton KI. Profile of movement demands of national football players in Australia. J Sci Med Sport, 2006; 9(4): 334-41.

10. Cabri J, De Prof E, Dufour W, Clarys JP. The relationship between muscular strength and kick performance. In: Science and Football. Reilly, T, Lees, A, Davids, K, Murphy, W, eds. London: E. and F. N. Spon. 1998; 168-193.

11. Coopoo Y, Mcnaughton LR. Selected fitness profiles of football players in relation to their playing position. African
Gaurav et al. 2015

Journal for Physical, Health Education, Recreation and Dance, December (Supplement 2), 2012;189-197.

12. Fleishman EA. The structure and measurement of physical fitness. Englewood Cliffs, N.J.: Prentice- Hall, Inc.1964.

13. Getchell B. Physical Fitness: A Way of Life, 2nd ed. New York:John Wiley and Sons, Inc.1979.

14. Gil SM, Gil Ruiz F, Irazusta A, Irazusta J. Physiological and anthropometric characteristics of young soccer players according to their playing position: relevance for the selection process. J Strength Cond Res 2007; 21:438-45.

15. Johnson B L, Nelson JK. Practical measurements for evaluation in physical Education, 3rd Ed. Delhi: Surjeet Publications.1982.

16. Polman R, Walsh D, Bloomfield J, Nesti M. Effective conditioning of female soccer players. Journal of sports sciences, 2004; 22(2): 191-203.

17. Puga N, Ramos J, Agostinho J, Lomba, I, Costa O, Freitas F. Physical profile of a first division Portuguese professional soccer team. In: Science and Football II. Reilly, T, Clarys, J, and Stibbe, A, eds.London: E \& FN Spon, 1993; 40-42.

18. Reilly T, Thomas V. A motion analysis of work-rate in different positional roles in professional football match-play. Journal of Human Movement Studies, 1976; 2:87-89.

19. Rienzi E, Drust B, Reilly T, Carter JEL, Martin A. Investigation of anthropometric and work-rate profiles of elite South American international soccer players. Journal of Sports Medicine and Physical Fitness, 2000; 40: 162-169.

20. Reeves SL, Poh BK, Brown M, Tizzard NH, Ismail MN. Anthropometric measurements and body composition of English and Malaysian footballers. Malaysian Journal of Nutrition, 1999; 5: 79-86.

21. Sheppard JM, Young WB. Agility literature review: Classifications, training and testing. Journal of Sports Science, 2006; 24: $919-932$.

22. Smekal G, Von SP, Rihacek C, Pokan R, Hofmann P, Baron R, Tschan H, Bachi N. A physiological profile of tennis match play. Medicine and science in sports and exercise, 2001; 33(6): 999-1005.

23. Sporis G, Jukic I, Ostojic SM, Milanovic D. Fitness profiling in soccer: physical and physiologic characteristics of elite players." J Strength Cond Res, 2009; 23(7):1947-53.

24. Witvrouw E, Danneels L, Asselman P, D"Have T, Cambier D. Muscle flexibility as a risk factor for developing muscle injuries in male professional soccer players a prospective study. The American Journal of Sports Medicine, 2003; 31(1):41-46.

25. Wong $\mathrm{P}$, Hong Y. Soccer injury in the lower extremities. Br J Sports Med, 2005; 39(8): 473-82. 